\title{
Reply on the Letter by Stott et al. 'The Dilemma of Treating Subclinical Hypothyroidism: Risk that Current Guidelines Do More Harm than Good'
}

\author{
Leonidas H. Duntas ${ }^{\mathrm{a}}$ Georg Brabant ${ }^{\mathrm{b}}$ Fabio Monzanic Simon H.S. Pearce ${ }^{\mathrm{d}, \mathrm{e}}$ \\ Robin Patrick Peeters ${ }^{g}$ Salman Razvi ${ }^{d, f}$ Jean-Louis Wemeau ${ }^{\text {h }}$ \\ ${ }^{a}$ Endocrine Unit, Evgenidion Hospital, University of Athens, Athens, Greece; b Medizinische Klinik I, \\ Universitätsklinikum Schleswig-Holstein, Lübeck, Germany; ${ }^{C}$ Department of Clinical and Experimental Medicine, \\ Università di Pisa, Pisa, Italy; ${ }^{d}$ Institute of Genetic Medicine, Newcastle University, and ${ }^{\mathrm{R}}$ Royal Victoria Infirmary, \\ Newcastle upon Tyne, and ${ }^{\mathrm{f}}$ Queen Elizabeth Hospital, Gateshead, UK; ${ }^{9}$ Rotterdam Thyroid Center, Department of

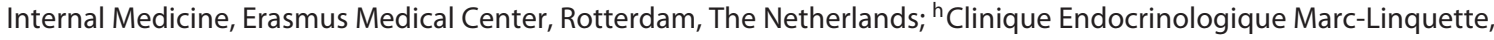 \\ $\mathrm{CHU}$, Lille, France
}

We appreciate the interest of Stott et al. [1] in the Management of Subclinical Hypothyroidism ETA Guidelines 2013 [2]. We are, however, somewhat puzzled by the authors' statement that the guidelines 'risk doing more harm than good', probably the result of misinterpretation of some recommendations of the guidelines.

The ETA Guidelines represent a meticulous interpretation of more than 140 articles and were, moreover, posted on the ETA website for about a month for criticism and comments. They offer a unique platform of expertise, supporting those involved in the diagnosis and treatment of both younger and older patients with subclinical hypothyroidism (SCH), in a spirit of collaboration for the benefit of our patients.

Stott et al. [1] basically agree with the guidelines that the wait-and-see approach and repeat thyroid testing in patients with $\mathrm{SCH}$ is a widely accepted concept. The measurement of thyroid auto-antibodies determines the risk of progression to overt hypothyroidism, especially if the thyroidstimulating hormone (TSH) level is above $2.5 \mathrm{mU} / \mathrm{l}[3]$. The guidelines are misrepresented by these comments, as we definitely do not recommend treatment based on auto-antibodies.

The categorization of the patients by age (60-70 years as moderately old, $>70$ years as older and $>80-85$ years as oldest old) is essential for the establishment of a diagnosis that should also consider 'agespecific reference ranges for serum TSH' (recommendation 14) in older people. It has clearly been shown that there is a widening of the reference range for serum TSH with increasing age $[4,5]$. In fact, a recent study from a large population in Scotland demonstrated a significant increase in the 97.5th centile of TSH (3.98-5.94 mU/l, respectively) with increasing age [6]. In addition, there are differences in the nature of the TSH changes with age between iodinedeficient and iodine-replete populations. We therefore do not agree with the authors that the consideration of age-specific guidelines is 'premature and overly complex' [1], but feel that this is important information that cannot be omitted from the guideline in an artificial attempt to avoid complexity.

Stott et al. [1] are in agreement that levothyroxine treatment, depending on the degree of TSH suppression and age, is as- sociated with lower bone density, increased risk of fractures and atrial fibrillation. The guidelines specifically recommend (recommendation 15) that the oldest old subjects ( $>80-85$ years) with elevated serum $\mathrm{TSH} \leq 10 \mathrm{mU} / \mathrm{l}$ should be carefully followed with a wait-and-see strategy, generally avoiding hormonal treatment. This procedure is supported by a recent study showing that older patients are at particular risk for overtreatment, as their upper limit of normal for the level of TSH is slightly higher than that in younger patients [7]. Among 3,900 community-dwelling apparently euthyroid Caucasian Australian men over 70 years of age, those whose free thyroxine was normal but in the highest quartile were $20 \%$ more likely to have died over 6 years of follow-up.

Finally, we absolutely agree that a randomized controlled trial, such as the one by the TRUST-IEMO collaboration, is needed to reinforce decision making as to whether levothyroxine treatment is required and is beneficial in older patients with $\mathrm{SCH}$ and also to determine whether the oldest old may benefit from treatment. Accordingly, the guideline states that appropriately powered randomized controlled trials of levo-

\section{KARGER}

E-Mail karger@karger.com www.karger.com/etj
(C) 2014 European Thyroid Association

Published by S. Karger AG, Basel

$2235-0640 / 14 / 0032-0139 \$ 39.50 / 0$
Leonidas Duntas

Evgenidion Hospital, University of Athens Medical School

Papadiamantopoulou Street 20

GR-11528 Athens (Greece)

E-Mail ledunt@otenet.gr 
thyroxine in $\mathrm{SCH}$ patients, examining hard cardiovascular end points in various classes of age, are clearly warranted.

Based on these data and the present joint statement, it is therefore evident that the guidelines, especially recommendation 21 stating 'In the elderly, any treatment for $\mathrm{SCH}$ should be individualized, gradual and closely monitored', can be of undoubted assistance and will certainly not do harm.

\section{Disclosure Statement}

The authors declare no competing interests.

\section{References}

1 Stott DJ, Bauer DC, Ford I, Kearney P, Gussekloo J, Quinn TJ, Rodondi N, Smit J, Westerdorp R: The dilemma of treating subclinical hypothyroidism: risk that current guidelines do more harm than good. Eur Thyroid J 2014, DOI: 10.1159/000360621.

2 Pearce SHS, Brabant G, Duntas LH, Monzani F, Peeters RP, Razvi S, Wemeau JL: 2013 ETA Guideline: management of subclinical hypothyroidism. Eur Thyroid J 2013;2:215-228.
3 Vanderpump MP, Tunbridge WM, French JM, et al: The incidence of thyroid disorders in the community: a twenty-year follow-up of the Whickham Survey. Clin Endocrinol 1995; 43:55-68.

4 Surks MI, Hollowell JG: Age-specific distribution of serum thyrotropin and antithyroid antibodies in the US population: implications for the prevalence of subclinical hypothyroidism. J Clin Endocrinol Metab 2007;92:45754582 .

5 Atzmon G, Barzilai N, Hollowell JG, et al: Extreme longevity is associated with increased serum thyrotropin. J Clin Endocrinol Metab 2009;94:1251-1254.
6 Vadiveloo T, Donnan PT, Murphy MJ, Leese GP: Age- and gender-specific TSH reference intervals in people with no obvious thyroid disease in Tayside, Scotland: the Thyroid Epidemiology, Audit, and Research Study (TEARS). J Clin Endocrinol Metab 2013;98: 1147-1153.

7 Yeap BB, Alfonso H, Hankey GJ, et al: Higher free thyroxine levels are associated with allcause mortality in euthyroid older men: the Health in Men Study. Eur J Endocrinol 2013; 169:401-408. 